орієнтацій; спроможні розгорнуто й повно аналізувати себе, результати навчання, поведінку, бажання й потреби; прагнуть до самостійності, активності, ініціативності; наявність постійного самоконтролю й самооцінки.

Розглянуті критерії й показники та взаємозв'язки між компонентами ціннісносмислових орієнтацій учнів старших класів дають підстави зробити висновок, що рівень цього складного особистісного утворення прямо пропорційний до рівня розвитку його структурних компонентів, ступеня їх гармонійності та інтеграції.

Урахування ролі кожного з компонентів структури ціннісно-смислових орієнтацій старшокласників свідчить, що ефективне формування цього складного особистісного утворення вимагає врахування особливостей навчально-пізнавальної діяльності при вивченні математичних дисциплін, усвідомлення учнями значущості знань-цінностей, особистісних смислів у творчому розвитку їх особистості, свідомого та самостійного виконання ними системи послідовних активних навчальних дій з урахуванням інтересів, потреб, установок на саморозвиток, самопізнання, самовдосконалення, самоствердження. Тому процес формування ціннісно-смислових орієнтацій учнів старших класів у процесі вивчення математичних дисциплін вимагає створення дослідно-експериментальної програми й відповідних дидактичних умов, що сприяли б постійному усвідомленню цінності освіти й навчання як важливих чинників творчого розвитку особистості кожного старшокласника, вдосконаленню не лише навчальних дій, а й дій самопізнання, самовдосконалення, самоконтролю учнів.

\title{
Література
}

1. Баруліна Ю. О. Сутнісні характеристики i структура ціннісно-смислових орієнтацій учнів старшої школи у процесі навчання / Ю. О. Баруліна // Сталий розвиток промисловості та суспільства : міжнародна науково-технічна конференція (Кривий Ріг, 20-22 травня 2015 року): [матеріали конференції].- Кривий Ріг: Криворізький національний університет, 2015. - С. 3-4. 2. Беспалько В. П. Слагаемые педагогической технологии / В. П. Беспалько. - Москва : Педагогика, 1989. - 191 с. 3. Великий тлумачний словник сучасної української мови (з дод. і допов.) / уклад. і голов. ред. В. Т. Бусел. - Київ; Ірпінь : ВТФ «Перун», 2005. - 1728 с. 4. Загвязинский В. И. Идея, замысел и гипотеза педагогического исследования / В. И. Загвязинский, А. Т. Закирова // Педагогика. - 1997. № 2. - С. 9-14. 5. Монахов Н. И. Изучение эффективности воспитания: Теория и методика (Опыт експериментального исследования) / Н. И. Монахов. - Москва : Педагогика, 1981. 144 с. 6. Словарь иностранных слов / под ред. Н. Г. Комлева. - Москва : ИНФРА-М, 2006. $174 \mathrm{c}$

\section{ФОРМУВАННЯ ТВОРЧОЇ УЯВИ МОЛОДШИХ ШКОЛЯРІВ НА УРОКАХ ЛІТЕРАТУРНОГО ЧИТАННЯ ЗАСОБАМИ НОВІТНІХ ТЕХНОЛОГІЙ}

Білоконна Н. I. Формування творчої уяви молодших школярів на уроках літературного читання засобами новітніх технологій.

Статтю присвячено методиці організації і проведення уроків літературного читання у початковій школі. Автор аналізує методичні прийоми, що сприяють організації спільної навчальної діяльності учнів на уроках читання; розглядає сучасні освітні технології, які $є$ найбільш ефективними для формування творчої уяви молодших школярів у процесі 
вивчення художніх творів.

Ключові слова: методика, літературне читання, початкова школа, методичні прийоми, спільна навчальна діяльність, сучасні освітні технології, творча уява, молодший школяр, художні твори, процес формування.

Белоконная Н. И. Формирование творческого воображения младших школьников на уроках литературного чтения средствами новейших технологий.

Статья посвящена методике организации и проведения уроков литературного чтения в начальной школе. Автор анализирует методические приёмы, способствующие организации совместной учебной деятельности учащихся на уроках чтения; рассматривает современные образовательные технологии, которые являются наиболее эффективными для формирования творческого воображения младших школьников в процессе изучения художественных произведений.

Ключевые слова: методика, литературное чтение, начальная школа, методические приёмы, совместная учебная деятельность, современные образовательные технологии, творческое воображение, младший школьник, художественные произведения, процесс формирования.

Belokonnaia N. I. The formation of a creative imagination of junior pupils at the lessons of literary reading by means of innovation technologies.

The article dealth with the methods of organization and carrying out the lessons of literary reading at a primary school. The author analyzes traditional and other methodical techniques promoting the organization of pupils' team-work at the reading lesson; considers modern educational technologies as the most effective for formation of a creative imagination of junior pupils in the process of studying literary works.

Key words: methods, literary reading, primary school, methodical techniques, team-work, modern educational technologies, creative imagination, junior pupil, literary works, the process of formation.

Творчий розвиток особистості за всіх часів розглядався як один із пріоритетних напрямів освіти. XXI століття - це ера принципово нових знань і способів пізнання. Здатність до творчості дійсно стає необхідною умовою орієнтації людини у швидкозмінних і швидкоплинних процесах життєтворчості.

Значну кількість наукових праць вітчизняних i зарубіжних авторів присвячено проблемам виховання творчої особистості в різних видах діяльності (I. Булах, I. Бех, Г. Костюк, С. Рубінштейн, О. Скрипченко та ін.); формування й розвитку творчих здібностей учнів (О. Митник, В. Моляко, О. Савченко).

Сучасні науковці (В. Барко, І. Барташнікова, Н. Білоконна, Г. Бондаренко, З. Друзь, С. Ковальова, І. Кравцова, В. Науменко та ін.) головною ознакою творчої особистості вважають ii творчі якості, тобто індивідуально-психологічні особливості дитини, які відповідають вимогам творчої діяльності і є умовою іiі успішного виконання [4, с. 4]. Одним iз важливих показників творчих якостей молодшого школяра є творча уява.

Mema cmammi - проаналізувати методичні прийоми та схарактеризувати сучасні освітні технології, що якнайкраще сприяють формуванню творчої уяви молодших школярів на уроках літературного читання.

В умовах сьогодення початкова школа не лише навчає, вона формує особистість, яка 
здатна вчитися у співвіднесенні зі своїми особистісно значущими потребами. Творчість норма дитячого розвитку, органічно притаманна дитині з раннього віку. Кожному періоду властиві певні домінанти творчої діяльності.

Внутрішній світ людини складається з сукупності психічних процесів (відчуття, уявлення, емоції. потреби, мотиви, здібності). Вони є предметом відображення у свідомості особистості. Дбаючи про розвиток творчих здібностей у молодших школярів, залучаючи їх до творчої праці, ми створюємо необхідні умови для розвитку всіх без винятку психічних якостей учнів. Уява - психічний процес, що полягає у створенні людиною нових образів, думок на основі ії попереднього досвіду. Розвиток уяви є необхідним фактором підготовки учнів до творчої діяльності [3, с. 444].

Шкільна практика свідчить, що в розвитку творчих здібностей учнів уява, фантазія відіграють надзвичайно важливу роль. За умов правильної організації роботи над розвитком уяви дітей у їхній діяльності з'являється особливий момент творчості, момент творення нового. 3 розвитком уяви, фантазії учень стає спроможним не лише відбивати у своїй свідомості об'єктивну дійсність, створюючи образи, уявлення, поняття про неї в такому вигляді, в якому вона $\epsilon$ тепер, а й уявляти ï в перетвореному вигляді, такою, якою вона могла бути ябо якою хотілося б її бачити чи мати [4, с. 10].

Уроки літературного читання у початкових класах покликані сформувати активного читача, здатного до самостійної читацької та літературно- творчої діяльності, забезпечити йому мовленнєвий, літературознавчий, інтелектуальний розвиток, сформувати моральноестетичні уявлення, поняття i цінності, збагатити почуття, виховати потребу в систематичному читанні. Крім того, мета літературного читання - формування читацької компетентності учнів, яка $\epsilon$ базовим складником комунікативної i пізнавальної компетентностей, ознайомлення учнів 3 дитячою літературою як мистецтвом слова, підготовка їх до систематичного вивчення літератури в основній школі. Опрацювання художніх творів різних жанрів сприяє формуванню практичних умінь щодо смислового i структурного аналізу тексту (вдосконалюються уміння знаходити і пояснювати зв'язки між реченнями, абзацами і частинами тексту; орієнтуватися у його структурі; набувають подальшого розвитку уміння запитувати й відповідати та ін.), позитивно впливає на розвиток емоційної сфери учнів, сприяє формуванню у них емоційної культури.

Сучасна початкова школа широко послуговується інноваційними педагогічними технологіями. Науковцями (О. Біда, О. Козлова, О. Комар, В. Паламарчук, О. Пометун, О. Савченко, Г. Селевко, А. Хуторський та ін.) визначені ознаки, за якими інновацію можна віднести до технології:

- наявність наукового проекту;

- націленість на конкретний результат, можливість відтворення будь-яким педагогом під час вивчення будь-якої навчальної дисципліни у будь-якому класі;

- розробленість діагностувальних методик для визначення ефективності технології [5, с. 24].

Аналіз публікацій, вивчення передового педагогічного досвіду, спостереження за навчально-виховним процесом дають підстави стверджувати, що в навчанні молодших школярів та формуванні кожного учня як творчої особистості будуть ефективними такі методи: «мозковий штурм», «коло ідей», «асоціативний кущ», «мікрофон» та ін. Схарактеризуємо їх докладніше:

«Мозковий штурм» - відома інтерактивна технологія колективного обговорення, що широко використовується для розв'язання конкретної проблеми. Основна мета цієї 
технології- зібрати якомога більше ідей щодо розглядуваної проблеми від усіх учнів протягом обмеженого періоду часу. Після презентації проблеми та чіткого формулювання проблемного питання, яке доцільно записати на дошці, пропонуємо всім учням висловити ідеї, коментарі, навести фрази чи слова, пов’язані з цією проблемою. На дошці чи великому аркуці паперу записуємо без жодного коментаря усі пропозиції в порядку їх виголошення. Наші спостереження свідчать, що ефективність «мозкового штурму» значно зростає за умови дотримання вчителем слушних порад сучасних науковців:

1. Під час «висування ідей» не пропускайте жодної.

2. Заохочуйте всіх до висування якомога більшої кількості ідей. Варто фіксувати i підтримувати навіть фантастичні ідеї.

3. Кількість ідей заохочується. В умовах висування великої кількості ідей учасники штурму мають можливість пофантазувати.

4. Спонукайте всіх учнів розвивати або змінювати ідеї інших. Об'єднання чи заміна висунутих раніше ідей сприяє розвитку творчої уяви учнів та часто спонукає до висунення нових, що перевищують первинні.

5. На завершення обговорюємо й оцінюємо всі запропоновані ідеї [4, с. 178].

Як бачимо, мозковий штурм спонукає учнів виявляти творчу уяву, дає можливість вільно висловлювати свої думки.

«Коло ідей» - ще одна інтерактивна технологія, що допомагає вирішити гострі, суперечливі питання за допомогою створення списку ідей шляхом залучення усіх школярів до обговорення поставленого питання. Учні розподіляються у групи по 5-6 осіб, хоча вони будуть виконувати одне й те ж завдання, що складається 3 декількох питань, які групи представляють по черзі.

Обговорення в групі триває 7-8 хвилин. Учні вибирають найбільш обізнаного представника, який висловлює, обгрунтовує думку групи, підтверджуючи їі прикладами чи вибірковим зачитуванням тексту. Група слідкує за відповіддю, може доповнювати виступ чи спростовувати хибні думки.

Коли малі групи завершують виконання завдання, кожна з них по черзі озвучує лише один аспект проблеми, що обговорювалася. По колу вчитель запитує всі групи по черзі, поки не прозвучить вся інформація. Саме такий спосіб опитування дає можливість кожній групі розповісти про результати своєї роботи, уникаючи при цьому ситуації, коли перша група, що виступає, подає всю інформацію. Після обговорення всіх думок і пропозицій, відкидаються хибні твердження та усвідомлено сприймається ідейний зміст художнього твору.

За допомогою гри-вправи «асоціативний кущ» можна закріплювати різноманітні вміння й навички . На початку роботи вчитель визначає одним словом тему, над якою будуть працювать, а учні згадують, що виникає в пам'яті стосовно цього слова. Спочатку висловлюються найстійкіші асоціації, потім - другорядні. Учитель фіксує відповіді у вигляді своєрідного «куща», який поступово «розростається». Цей метод універсальний, адже може використовуватися на всіх етапах уроку [2, с. 17].

Технологія «Мікрофон» надає можливість кожному школяреві сказати щось швидко, по черзі, відповідаючи на запитання або висловлюючи власну думку чи позицію. Правила проведення: 1) говорити має тільки той, у кого $\epsilon$ «символічний» мікрофон; 2) подані відповіді не коментуються і не оцінюються; 3) коли хтось висловлюється, решта не має права перебивати, щось говорити, вигукувати з місця.

Особливе місце у навчально-виховному процесі початкової школи посідає ігрова технологія. У структурі уроку літературного читання ігрова діяльність може мати форму 
дидактичної гри, ігрової ситуації, ігрового прийому, ігрової вправи. Дидактичні ігри - це ігри, що входять безпосередньо до структури уроку і сприяють засвоєнню, поглибленню і закріпленню навчального матеріалу та $\epsilon$ засобом загального розвитку особистості, сформованості читацької компетентності тощо.

У багатьох наукових працях відображено різні підходи і до визначення сутності дидактичної гри. Так, науковці визначають сутність гри як:

1. Форму спілкування (саме в іграх розпочинається невимушене спілкування між дітьми. У грі всі їі учасники постійно взаємодіють, спілкуються між собою, що потребує дотримання певних правил і норм. Таким чином, у дитини нагромаджується соціальний досвід поведінки. Якщо ігрова діяльність займає багато часу в житті молодших школярів, то це сприяє виробленню у них звички поводитися культурно. 3 іншого боку, оптимістичний тон спілкування під час гри, позитивний емоційний настрій, а також знайома ігрова діяльність зумовлюють природність дій та вчинків дитини, що дає змогу вчителеві судити про рівень сформованості культури поведінки учня та бачити недоліки (М. Гончаров, Т. Ладивір, М. Лісіна, В. Семенов, В. Сушко, Н. Філатова)).

2. Форму діяльності (гра $є$ найприроднішою і найпривабливішою діяльністю для дітей. У процесі гри в дітей виробляється звичка зосереджуватися, працювати вдумливо, самостійно, розвивається увага, пам'ять, жадоба до знань. Задовольняючи свою природну невсипущу потреба в діяльності, в процесі гри дитина «добудовує» в уяві все, що недоступне їй в навколишній дійсності, у захопленні не помічає, що вчиться - пізнає нове, запам'ятовує, орієнтується в різних ситуаціях, поглиблює раніше набутий досвід, порівнює запас уявлень, понять, розвиває фантазію (Л. Виготський, Д. Ельконін).

3. Форму розумового розвитку (у грі найповніше проявляється індивідуальні особливості, інтелектуальні можливості, нахили, здібності дітей. Гра належить до традиційних і визнаних методів навчання і виховання, дошкільників, молодших школярів і підлітків. Цінність цього методу полягає в тому, що в ігровій діяльності освітня, розвиваюча й виховна функція перебувають у тісному взаємозв'язку. Гра як метод навчання організовує, розвиває учнів, розширює їхні пізнавальні можливості, виховує особистість [1, с. 21].

Дидактичні ігри, які використовуються на уроках літературного читання, уважаються літературними. Термін «літературна гра» має подвійне значення:

1) це художня творчість, гра мистецькими засобами за законами мистецтва, рівнозначна будь-якій соціальній грі (політичній, виховній, спортивній), однак відмінна за змістом, тут панують естетичні критерії;

2) літературні ігри вживаються як узагальнена назва певних жанрів, які стимулюють інтелектуальну активність та розвивають естетичний смак.

У методичному аспекті літературні ігри - це словесні, рольові, драматичні ігри, побудовані на літературному матеріалі, розваги з використанням літератури, що розвивають пам'ять, уяву, фантазію, дотепність і винахідливість учасників, один із дієвих засобів опрацювання літературного твору. До таких ігор відносяться інсценізація, вікторина, буріме, каламбур, шарада, чайнворд, анаграма, кросворд, ребус, метаграма, головоломка, криптограма, фігурний вірш тощо.

Найцікавішим прийомом організації творчої діяльності учнів вивчення прочитаного $є$ драматизація у всіх ii формах: читання по ролях, пантоміма, постановка живих картин, драматизація.

Ігри-драматизації - це ігри, що театралізуються, в яких діти розігрують або сюжети літературних творів (казки, байки, вірші і так далі), або фрагменти зі свого життя. Ці ігри 
широко використовуються у виховних цілях без попередньої підготовки по добре знайомому сюжету казки, яку діти знають напам’ять. «Рукавичка», «Вовк та козенята», «Півник і двоє мишенят»- всі ці сюжети, що подобаються молодшим школярам, можуть розігруватися ними багато разів і не набридати.

Пантоміма дозволяє через рух, 3'ясовувати і пояснювати зміст i форму твору. Наприклад, читаючи казку «Мудра дівчина», вчитель пропонує комусь 3 хлопців показати, як «Бідний прийшов додому, думав, думав та й зажурився».

Активізуючи й розвиваючи мислення молодших школярів на уроках літературного читання під час опрацювання художніх творів різних жанрів, вчитель тим самим створює основу для розвитку у них творчої уяви, мовлення, збагачення активного словника, оволодіння мовленнєвою компетентністю. Проаналізовані прийоми $\epsilon$ ігровими, вони допомагають глибше проникнути в зміст твору, викликають співчуття до героїв, стають засобом вираження власного ставлення до прочитаного.

Отже, використання інноваційних технологій у сучасній початковій школі позитивно впливає на засвоєння учнями навчального матеріалу, сприяє формуванню кожного школяра як творчої особистості.

\section{Література}

1. Білоконна Н. Дидактична гра на уроках літературного читання у 3 класі: [методич. посібник] / Н. Білоконна, В. Корольова. - Кривий Ріг : КПІ, 2014. - 79 с. 2. Білоконна Н. Виховні можливості уроків літературного читання / Н. Білоконна, І. Кравцова, О. Павлик // Почат. школа. - 2015. - № 10. - С. 38-42. 3. Друзь 3. В. Формування творчої особистості учня в позаурочний час / 3. В. Друзь, Н. І. Білоконна, 3. М. Мірошник : [монографічний посіб.].- Кн. 2. - Кривий Ріг : КДПУ, 2009. - 471 с. 4. Кравцова І. А. Формування творчих здібностей в учнів 3 класу на уроках читання: [методич. посіб.] / І. А. Кравцова, К. О. Кузьменко. - Кривий Ріг : КПІ, 2011. - 60 с. 5. Савченко О. Я. Методика читання в початкових класах / О. Я. Савченко. - Київ : Освіта, 2006. - 297 с.

УДК 373.3.091.2

Ніна Білоконна, Інна Кравцова

\section{ШЛЯХИ ПІДВИЩЕННЯ ЕФЕКТИВНОСТІ САМОПІДГОТОВКИ МОЛОДШИХ ШКОЛЯРІВ В УМОВАХ ГРУПИ ПРОДОВЖЕНОГО ДНЯ}

Білоконна Н. І., Кравцова I. А. Шляхи підвищення ефективності самопідготовки молодших школярів в умовах групи продовженого дня.

Статтю присвячено проблемі професійного становлення вихователя групи продовженого дня. Авторами подано рекомендації щодо вдосконалення самопідготовки як важливого режимного моменту ГПД; схарактеризовано умови, дотримання яких не лише сприяє формуванню самостійності молодших школярів та забезпечує якісне виконання ними домашніх завдань, а й позитивно впливає на загальний розвиток кожного учня як особистості.

Налагодження суб'єкт-суб'єктної взаємодії під час самопідготовки дозволить учням активно усвідомити важливість самостійного здобуття знань та формування на їх основі практичних умінь і навичок, зробить педагогічний процес у групі продовженого дня продуктивним і гармонійним.

Ключові слова: молодший школяр, домашні завдання, вихователь, група продовженого дня, самопідготовка, самостійність, умови ефективності роботи. 